\title{
MENGUKUR KINERJA UNIT SIMPAN PINJAM KOPARI CATRA GEMILANG MAGELANG TAHUN 2014 DENGAN ANALISIS BALANCED SCORECARD
}

\author{
Novia Candra Permatasari \\ Fakultas Ekonomi Universitas Mercu Buana Yogyakarta \\ Email: candra.permata@gmail.com \\ Rina Dwiarti \\ Prodi Manajemen Universitas Mercu Buana Yogyakarta \\ Email: rina@mercubuana-yogya.ac.id
}

\begin{abstract}
Abstrak
Pengukuran kinerja suatu perusahaan pada umumnya didasarkan pada rasio keuangan. Balanced scorecard merupakan suatu alat pengukuran kinerja yang menekankan pada keseimbangan faktor keuangan dan non keuangan yang menyeimbangkan empat perspektif yaitu perspektif keuangan, perspektif pelanggan, perspektif proses bisnis internal, perspektif pembelajaran dan pertumbuhan.

Penelitian ini bertujuan untuk mengukur kinerja Unit Simpan Pinjam Koperasi Pariwisata Catra Gemilang Magelang Tahun 2014 jika diukur menggunakan balanced scorecard. Pengukuran kinerja dilakukan dengan menganalisis keempat perspektif balanced scorecard yang dalam penelitian ini, masing-masing perspektif dibatasi pada variabel tertentu.

Dari hasil analisis data dapat diketahui bahwa pengukuran kinerja Unit Simpan Pinjam Kopari Catra Gemilang pada tahun 2014 dapat dikatakan baik. $\mathrm{Hal}$ ini berdasarkan hasil pemberian skor pada tiap variabel dalam keempat perspektif yang dirata-rata dan memperoleh skor sebesar 3,88 hingga termasuk dalam kategori baik.
\end{abstract}

Kata kunci: pengukuran kinerja, balanced scorecard.

\section{PENDAHULUAN}

Koperasi sebagai salah satu bentuk badan usaha di Indonesia, saat ini mengalami perkembangan yang cukup pesat. Berbagai jenis koperasi seperti

koperasi mahasiswa, koperasi pasar, koperasi pegawai, koperasi pariwisata, koperasi simpan pinjam hingga koperasi syariah dan banyak lagi jenis koperasi lainnya telah banyak berdiri di berbagai daerah. Hal ini sudah tentu mendorong adanya tingkat persaingan antar elemen koperasi yang semakin ketat. Apalagi sekarang dengan mudahnya ditemui badan usaha koperasi yang baru bermunculan dan semakin marak.

Untuk dapat bersaing di lingkungan yang ketat tentunya diperlukan strategi yang mampu mendorong kinerja yang baik bagi perusahaan. Penilaian atau pengukuran kinerja merupakan salah satu faktor yang penting dalam perusahaan.

Selain digunakan untuk menilai keberhasilan perusahaan, pengukuran kinerja juga dapat digunakan sebagai dasar untuk mengevaluasi hasil kerja dari periode yang lalu. Sehubungan 
dengan hal itu, pengukuran kinerja sebaiknya dilakukan secara komprehensif, sehingga pengambilan keputusan berkaitan dengan strategi dapat dilakukan secara menyeluruh. Dengan demikian strategi tersebut akan dapat mengakomodasi setiap perspektif yang terlibat dalam menentukan keberhasilan perusahaan.

Penilaian kinerja pada umumnya didasarkan pada rasio keuangan. Dengan adanya persaingan yang sangat ketat seperti yang telah diuraikan sebelumnya maka perusahaan dalam hal ini koperasi dituntut untuk mampu berpikir dan mengembangkan manajemen strategik untuk dapat mencapai sasaran strategik dalam mencapai tujuan pada hasil keuangan baik dalam jangka pendek maupun jangka panjang.

Sehubungan dengan hal tersebut, Robert S. Kaplan dari Harvard Business School memperkenalkan suatu alat untuk pengukuran kinerja perusahaan, yaitu Balanced Scorecard. Balanced Scorecard merupakan contemporary management tool yang digunakan untuk mendongkrak kemampuan organisasi dalam melipatgandakan kinerja keuangan. Konsep Balanced Scorecard menekankan pada keseimbangan faktor keuangan dan non keuangan. Faktor tersebut meliputi faktor internal (karyawan dan organisasi) dan faktor eksternal (pemegang saham dan pelanggan) serta faktor jangka pendek (operasional) dan faktor jangka panjang (visi dan misi) (Kurnianto, 2006:36). Balanced Scorecard merupakan alat ukur kinerja yang menyeimbangkan empat perspektif yaitu perspektif keuangan, perspektif pelanggan, perspektif proses bisnis internal, perspektif belajar dan berkembang.

Perspektif keuangan yaitu suatu analisis kinerja perusahaan yang inputnya berupa data-data keuangan perusahaan seperti laporan laba rugi, neraca dan laporan perubahan modal. Perspektif pelanggan, merupakan analisis yang menitikberatkan pada segmen pelanggan dan segmen pasar di mana perusahaan akan beroperasi. Perspektif proses bisnis internal adalah analisis yang berkaitan dengan internal penting yang dimiliki perusahaan, merupakan feed back (umpan balik) perusahaan kepada konsumen, yang terdiri dari proses operasi, inovasi dan proses pelayanan penjual. Perspektif proses belajar dan pertumbuhan yaitu analisis tentang kemampuan perusahaan dalam menganalisis pertumbuhan jangka panjang perusahaan.

Balanced scorecard dengan keempat perspektif yang menjadi tolak ukur tentunya memiliki keunggulan lebih dibandingkan dengan pengukuran kinerja yang hanya berdasarkan rasio keuangan saja. Rasio Keuangan hanya mengukur kinerja koperasi berdasarkan segi keuangan saja, padahal hasil keuangan yang baik belum tentu menunjukkan kinerjanya berjalan dengan baik pula. Sedangkan Balanced Scorecard mampu memberikan penilaian berdasarkan empat aspek yang kesemuanya berdampak pada hasil keuangan namun juga menunjukkan hasil kinerja dari aspek lainnya secara lebih menyeluruh. Keunggulan pendekatan Balanced Scorecard dalam perencanaan sistem strategik adalah mampu menghasilkan rencana strategik yang memiliki karakteristik sebagai berikut (Mulyadi, 2009):

1. Komprehensif

Balanced Scorecard memperluas perspektif yang dicakup dalam perencanaan strategis dan sebelumnya hanya terbatas pada perspektif keuangan meluas ke ketiga perspektif lainnya.

2. Koheren 
Balanced Scorecard mewajibkan personal membangun hubungan sebab akibat di antara berbagai sasaran strategik yang dihasilkan dalam perencanaan strategik.

3. Seimbang

Keseimbangan sasaran strategik yang dihasilkan oleh system perencanaan strategik penting untuk menghasilkan kinerja berjangka panjang.

4. Terukur

Pengukuran sasaran-sasaran strategik yang dihasilkan oleh sistem perencanaan strategik menjanjikan ketercapaian berbagai sasaran strategik yang dihasilkan oleh sistem tersebut.

Keunggulan pengukuran Balanced Scorecard ini menunjukkan bahwa Balanced Scorecard mampu menjadi alat ukur yang baik terhadap kinerja koperasi secara lebih menyeluruh. Balanced Scorecard menjadi alat ukur yang tepat guna dalam menilai aspek-aspek kinerja koperasi berdasarkan keempat perspektif yang menjadi fokus serta mampu memberikan keunggulan atas hasil penilaian yang dihasilkan.

Dengan mengimplementasikan Balanced Scorecard, diharapkan koperasi-koperasi ini akan mampu bersaing dan berkembang dengan baik. Di samping itu diharapkan akan mampu meningkatkan daya tarik yang luar biasa bagi para investor, karena para investorlah yang akan memacu pertumbuhan perekonomian secara keseluruhan. Kesediaan dan komitmen para investor untuk menginvestasikan modal ke badan usaha khususnya koperasi akan sangat ditentukan oleh kemampuan manajemen dalam menunjukkan kompetensi mereka untuk menjadikan organisasi mereka sebagai institusi pelipatganda kekayaan. Implementasi Balanced Scorecard dalam sistem perencanaan kinerja koperasi jangka panjang merupakan langkah strategik yang berdampak besar terhadap kemampuan manajemen dalam melipatgandakan kinerja koperasi yang bersangkutan baik dari aspek keuangan maupun aspek nonkeuangan.Dengan menggunakan metode Balanced Scorecard diharapkan penilaian kinerja koperasi dapat diperoleh hasil yang menyeluruh melalui keempat perspektif tersebut. Hal lain yang mendorong peneliti untuk melakukan penelitian

pada Unit Simpan Pinjam Kopari Catra Gemilang Magelang adalah berbagai berita mengenai prestasi cemerlang yang telah diraih oleh Koperasi Catra Gemilang. Selain itu pula, koperasi ini sangat mendukung jalannya kepariwisataan di daerah Borobudur Magelang dengan mengembangkan berbagai jenis usaha dari modal koperasi.

Dari hal tersebut, penulis sangat antusias untuk dapat mengukur kinerja Unit Simpan Pinjam Kopari Catra Gemilang Magelang dengan analisis Balanced Scorecard sehingga penulis mampu untuk menelaah secara komprehensif melalui keempat perspektif dalam Balanced Scorecard untuk mampu membuktikan hasil kinerja koperasi apakah sesuai dengan prestasi yang telah dicapai.

\section{Permasalahan}

Bagaimanakah kinerja Unit Simpan Pinjam (USP) Kopari Catra Gemilang Magelang Tahun 2014 jika diukur menggunakan Balanced Scorecard?

\section{Tujuan Penelitian}

Adanya suatu penelitian tentunya memiliki tujuan. Adapun yang menjadi tujuan dari penelitian ini adalah untuk mengetahui kinerja keuangan Unit Simpan Pinjam Kopari Catra Gemilang Magelang Tahun 2014 jika diukur menggunakan Balanced Scorecard

\section{LANDASAN TEORI}




\section{Pengertian dan Tujuan Koperasi}

Koperasi adalah badan usaha yang beranggotakan orang-orang atau badan hukum koperasi dengan berlandaskan kegiatannya berdasarkan prinsip koperasi sekaligus sebagai gerakan ekonomi rakyat yang berdasarkan atas azas kekeluargaan (Departemen Koperasi: 1992). Artinya koperasi sebagai unit bisnis diberi kesempatan untuk menjalankan usaha dalam rangka memperoleh keuntungan namun harus tetap tidak meninggalkan karakteristik dan prinsip-prinsip koperasi telah ditetapkan.

Tujuan koperasi adalah memajukan kesejahteraan anggota pada khususnya dan masyarakat pada umumnya serta ikut membangun tatanan perokonomian nasional dalam rangka mewujudkan masyarakat yang maju, adil, dan makmur berlandaskan Pancasila dan UUD 1945 (Departemen Koperasi: 1992).

Kesejahteraan anggota merupakan prioritas utama yang harus dipegang koperasi, namun demikian harus tetap diusahakan tercapainya kemakmuran, keadilan dan kemajuan koperasi, karena kenajuan koperasi tidak terlepas dari partisipasi anggota dan pengelolaan secara profesional.

\section{Penilaian Kinerja}

Menurut Mulyadi (2009), kinerja adalah istilah umum yang digunakan untuk menunjukkan sebagian atau seluruh tindakan atau aktivitas dari suatu organisasi pada suatu periode. Pengukuran kinerja adalah tindakan pengukuran yang dapat dilakukan terhadap berbagai aktivitas dalam rantai nilai yang ada pada perusahaan. Hasil pengukuran menjadi evaluasi yang digunakan sebagai umpan balik atas prestasi yang telah dicapai dan perencanaan strategi berikutnya.

Penilaian kinerja sesungguhnya merupakan penilaian atas perilaku manusia dalam melaksanakan peran yang mereka mainkan dalam organisasi (Mulyadi, 2009). Penilaian kinerja adalah penentuan secara periodik efektivitas operasional suatu organisasi, bagian organisasi dan karyawan berdasarkan sasaran, standar dan kriteria yang telah ditetapkan sebelumnya. Pengukuran kinerja merupakan usaha formal yang dilakukan oleh manajemen untuk mengevaluasi hasil-hasil kegiatan yang telah dilakukan oleh masing-masing pusat pertanggungjawaban dibandingkan dengan tolak ukur yang telah ditetapkan. Ukuran kinerja didesain untuk menilai seberapa baik aktivitas dilakukan dan dapat mengidentifikasi apakah telah dilakukan perbaikan yang berkesinambungan. Pengukuran kinerja akan memberikan umpan balik untuk mengambil tindakan yang korektif.

Penilaian/pengukuran kinerja yang biasa dilakukan oleh perusahaan sebagai tolak ukur hasil kinerja adalah melalui penilaian kinerja keuangan. Pengukuran kinerja ini merupakan sistem pengukuran kinerja tradisional yang hasilnya kurang mampu menunjukkan hasil kinerja secara menyeluruh dan ekspektasi hasil kinerja untuk jangka panjang. Ukuran keuangan yang biasa digunakan dalam pengukuran kinerja adalah rasio-rasio keuangan yang meliputi:

1. Rasio likuiditas yang mengukur kemampuan perusahaan untuk memenuhi kewajiban jangka pendek bila jatuh tempo.

2. Rasio leverage yang mengukur hingga sejauh mana perusahaan dibiayai oleh hutang.

3. Rasio aktivitas yang mengukur seberapa efektif manajemen yang ditujukan oleh laba yang dihasilkan dari penjualan dan investasi perusahaan.

4. Rasio pertumbuhan yang mengukur kemampuan perusahaan mempertahankan posisi ekonominya didalam pertumbuhan ekonomi dan industri. 
5. Rasio penilaian yang mengukur kemampuan manajemen dalam menciptakan nilai pasar yang melampaui pengeluaran biaya investasi.

Menurut Robert S Kaplan dan David P Norton kelemahan kelemahan pengukuran kinerja yang menitik beratkan pada kinerja keuangan yaitu :

1. Ketidakmampuan mengukur kinerja harta-harta tidak tampak (intangible assets) dan harta-harta intelektual (sumber daya manusia ) perusahaan.

2. Kinerja keuangan hanya mampu bercerita mengenai sedikit masa lalu perusahaan dan tidak mampu sepenuhnya menuntun perusahaan ke arah yang lebih baik.

Berdasarkan hal tersebut semakin jelas bahwa pengukuran kinerja perusahaan dengan tolok ukur keuangan saja belum menjamin bahwa perusahaan akan memperoleh sukses di masa mendatang. Terlebih lagi dengan adanya kemajuan teknologi informasi yang terjadi sekarang ini, tidak mungkin bagi perusahaan untuk memperoleh keunggulan bersaing hanya dengan tolak ukur keuangan atau dengan hanya mengelola aktiva saja. Dengan demikian perusahaan memerlukan alat ukur baru untuk mengukur kinerja bisnisnya.

\section{Tujuan dan Manfaat Penilaian Kinerja}

Tujuan utama dari penilaian kinerja adalah untuk memotivasi personel dalam mencapai sasaran organisasi dan dalam memenuhi standar perilaku yang telah ditetapkan sebelumnya, sehingga membuahkan tindakan dan hasil yang diinginkan oleh organisasi. Tujuan pengukuran kinerja dalam sebuah perusahaan atau organisasi yakni memberikan motivasi pada karyawan agar mampu mengimplementasikan strategi dari suatu unit bisnis dengan baik (Sipayung:2009). Tujuan dari penilaian kinerja untuk memotivasi karyawan sehingga mencapai sasaran organisasi dan mematuhi segala standar perilaku yang

diterapkan oleh perusahaan maupun organisasi (Mulyadi, 2009:420). Dapat dikatakan pula bahwa hasil penilaian kinerja digunakan sebagai dasar pemberian kompensasi, sebagai staffing decision dan sebagai dasar mengevaluasi sistem kinerja. Penilaian kinerja dilakukan untuk meminimalkan perilaku yang tidak semestinya dilakukan agar tujuan organisasi dapat tercapai.

Penilaian kinerja dapat dimanfaatkan oleh manajemen untuk:

1. Mengelola operasi organisasi secara objektif dan efisien melalui pemotivasian karyawan secara maksimum.

2. Membantu pengambilan keputusan yang bersangkutan dengan karyawannya seperti promosi, pemberhentian dan mutasi.

3. Mengidentifikasi kebutuhan pelatihan dan pengembangan karyawan dan untuk menyediakan kriteria seleksi dan evaluasi program pelatihan karyawan.

4. Menyediakan umpan balik bagi karyawan mengenai bagaimana atasan mereka menilai kinerja mereka.

5. Menyediakan suatu dasar bagi distribusi penghargaan.

\section{Balanced Scorecard}

Menghadapi banyaknya persaingan, suatu perusahaan membutuhkan alat-alat strategi bisnis agar dapat mencapai keberhasilan di masa mendatang. Seperti yang telah dijabarkan pada penjelasan sebelumnya, bahwa pada era reformasi dan persaingan yang ketat perusahaan memerlukan alat kontrol baru dalam mengukur kinerja bisnisnya.

Balanced Scorecard terdiri dari dua kata yaitu balanced dan scorecard. Scorecard artinya kartu skor, maksudnya adalah kartu skor yang akan digunakan untuk merencanakan skor 
yang diwujudkan di masa yang akan datang, sedangkan balanced artinya berimbang, maksudnya adalah untuk mengukur kinerjaseseorang diukur secara berimbang dari dua perspektif yaitu keuangan dan non keuangan, jangka pendek dan jangka panjang, intern dan ekstern (Mulyadi, 2005). Balanced Scorecard adalah metode penilaian kinerja perusahaan dengan menggunakan aspek keuangan dan non keuangan yang dituangkan dalam empat perspektif dalam mengukur kinerja perusahaan yaitu: perspektif keuangan, pelanggan, proses bisnis internal serta proses pembelajaran dan pertumbuhan. Dari keempat perspektif tersebut dapat dilihat bahwa Balanced Scorecardmeliputi perspektif keuangan dan non keuangan (Mulyadi, 2009:7).

Menurut Pratiwi (2010), manfaat penggunaan Balanced Scorecard adalah:

1. Keseimbangan antara pengukuran internal (proses bisnis internal serta proses pembelajaran dan pertumbuhan) dan juga pengukuran eksternal yang ditujukan untuk pemilik badan usaha dan pelanggan.

2. Keseimbangan antara outcomes measures (pengukuran keluaran) yang merupakan hasil dari masa lampau dan performance driver (pemicu kerja) dimasa depan.

3. Keseimbangan antara unsur obyektivitas yang berkaitan dengan pengukuran hasil terdahulu dan unsur subyektivitas yang berkaitan dengan pengukuran pemicu kinerja di masa depan.

\section{Perspektif Balanced Scorecard}

Adapun perspektif-perspektif yang digunakan dalam Balanced Scorecard meliputi:

1. Perspektif Keuangan (Finansial Perspective)

Perspektif keuangan tetap menjadi perhatian dalam Balanced Scorecard karena ukuran keuangan merupakan ikhtisar dari konsekuensi ekonomi yang terjadi akibat keputusan dan tindakan ekonomi yang diambil. Tujuan pencapaian kinerja keuangan yang baik merupakan fokus dari tujuan-tujuan yang ada dalam tiga perspektif lainnya. Sasaransasaran perspektif keuangan dibedakan pada masing-masing tahap dalam siklus

bisnis yang oleh Kaplan dan Norton dibedakan menjadi tiga tahap (Chamdan, 2010):

a. Growth (Berkembang)

Berkembang merupakan tahap pertama dan tahap awal dari siklus kehidupan bisnis.

Pada tahap ini suatu perusahaan memiliki tingkat pertumbuhan yang sama sekali atau paling tidak memiliki potensi untuk berkembang. Untuk menciptakan potensi ini, kemungkinan seorang manajer harus terikat komitmen untuk

mengembangkan suatu produk atau jasa baru, membangun dan mengembangkan fasilitas produksi, menambah kemampuan operasi, mengembangkan sistem, infrastruktur dan jaringan distribusi yang akan mendukung hubungan global, serta mengasuh dan mengembangkan hubungan dengan pelanggan.

Perusahaan dalam tahap pertumbuhan mungkin secara aktual beroperasi dengan cash flow negatif dan tingkat pengembalian atas modal yang rendah. Investasi yang ditanam untuk kepentingan masa depan sangat memungkinkan memakai biaya yang lebih besar dibandingkan dengan jumlah dana yang mampu dihasilkan dari basis operasi yang ada sekarang, dengan produk dan jasa dan konsumen yang masih terbatas. Sasaran keuangan untuk growth

stage menekankan pada pertumbuhan penjualan di dalam pasar baru dari konsumen baru dan atau dari produk dan jasa baru. 
b. Sustain Stage (Bertahan)

Bertahan merupakan tahap kedua yaitu suatu tahap dimana perusahaan masih melakukan investasi dan reinvestasi dengan mempersyaratkan tingkat pengembalian yang terbaik. Dalam tahap ini perusahaan berusaha mempertahankan pangsa pasar yang ada dan mengembangkannya apabila mungkin.

Investasi yang dilakukan umumnya diarahkan untuk menghilangkan kemacetan, mengembangkan kapasitas dan meningkatkan perbaikan operasional secara konsisten. Pada tahap ini perusahaan tidak lagi bertumpu pada strategi-strategi jangka panjang. Sasaran keuangan pada tahap ini lebih diarahkan pada besarnya tingkat pengembalian atas investasi yang dilakukan.

c. Harvest (Panen)

Tahap ini merupakan tahap kematangan (mature), suatu tahap dimana perusahaan melakukan panen (harvest) terhadap investasi mereka. Perusahaan tidak lagi melakukan investasi lebih jauh kecuali hanya untuk memelihara dan perbaikan fasilitas, tidak untuk melakukan ekspansi atau membangun suatu kemampuan baru. Tujuan utama dalam tahap ini adalah memaksimumkan arus

kas yang masuk ke perusahaan. Sasaran keuangan untuk harvest adalah cash flow maksimum yang mampu dikembalikan dari investasi di masa lalu.Dalam perspektif financial, balanced scorecard diterapkan untuk membantu tercapainya tujuan keuangan. Tujuan keuangan menggambarkan tujuan jangka panjang perusahaan. Tujuan keuangan menjadi fokus dan ukuran di semua perspektif scorecard lainnya.

Pengukuran kinerja keuangan menunjukkan apakah perencanaan dan pelaksanaan strategi memberikan perbaikan yang mendasar, perbaikan pada sasaran yang secara khusus berhubungan dengan keuntungan yang terukur.

\section{Perspektif Pelanggan}

Pada masa lalu seringkali perusahaan mengkonsentrasikan diri pada kemampuan internal dan kurang memperhatikan kebutuhan konsumen. Sekarang strategi perusahaan telah bergeser fokusnya dari internal ke eksternal. Kepuasan pelanggan sebagai salah satu tolak ukur penilaian perspektif pelanggan sangat tergantung pada persepsi pelanggan. Jika apa yang diharapkan pelanggan sesuai dengan kinerja yang diberikan maka pelanggan akan terpuaskan. Tjiptono (2005) menyatakan unsur-unsur pembentukan kepuasan pelanggan terdiri dari:

1. Bukti langsung (tangibles) meliputi fasilitas fisik, perlengkapan, pegawai, dan sarana komunikasi.

2. Daya tanggap (responsiveness) yaitu keinginan para staf untuk membantu para pelanggan dan memberikan pelayan dengan tanggap.

3. Keandalan (reliability) yaitu kemampuan memnerikan pelayanan yang dijanjikan dengan segera, akurat, dan memuaskan.

4. Jaminan (assurance) yaitu mencakup pengetahuan, keamanan, kesopanan dan sifat dapat dipercaya yang dimiliki para staf, bebas dari bahaya, resiko, dan keragu-raguan.

5. Empati (emphaty) meliputi kemudahan dalam melakukan hubungan komunikasi yang baik, perhatian pribadi, dan memahami kebutuhan para pelanggan.

Setiap perusahaan yang memperhatikan kepuasan pelanggan akan memperoleh beberapa manfaat pokok, yaitu (Tjiptono, 2005): 
1. Reputasi perusahaan semakin positif dimata masyarakat pada umumnya dan pelanggan pada khususnya.

2. Dapat mendorong terciptanya loyalitas pelanggan.

3. Memungkinkan terciptanya rekomendasi dari mulut ke mulut (word of mouth) yang menguntungkan bagi perusahaan sehingga semakin banyak orang yang akan membeli dan menggunakan produk perusahaan.

4. Meningkatkan volume penjualan dan keuntungan.

5. Hubungan antara perusahaan dan para pelanggannya menjadi harmonis.

6. Mendorong setiap anggota organisasi untuk bekerja dengan tujuan serta kebanggaan yang lebih baik.

7. Menekan biaya melayani pelanggan sebagai dampak faktor familiaritas dan relasi khusus dengan pelanggan.

8. Terbukanya peluang melakukan penjualan silang (cross selling) produk.

\section{Perspektif Proses Bisnis Internal}

Dalam proses bisnis internal, manajer harus bisa mengidentifikasi proses internal yang penting dimana perusahaan diharuskan melakukan dengan baik karena proses internal tersebut mempunyai nilai-nilai yang diinginkan konsumen dan dapat memberikan pengembalian yang diharapkan oleh para pemegang saham.

Para manager harus memfokuskan perhatiannya pada proses bisnis internal yang menjadi penentu kepuasan pelangan kinerja perusahaan dari perspektif pelanggan. Kinerja dari perspektif tersebut diperoleh dari proses kinerja bisnis internal yang diselenggarakan perusahan. Perusahaan harus memilih proses dan kompetensi yang menjadi unggulannya dan menentukan ukuran-ukuran untuk menilai kinerja-kinerja proses dan kompetensi tersebut.

Secara umum Kaplan dan Norton (2000) dalam Chamdan (2010) membagi tahapan proses bisnis internal ini menjadi 3 prinsip dasar yaitu :

1. Inovasi

Pengukuran kinerja dalam proses inovasi selama ini kurang mendapatkan perhatian, dibandingkan pengukuran kinerja yang dilakukan dalam proses operasi. Pada tahap ini perusahaan mengidentifikasikan keinginan dan kebutuhan para pelanggan dimasa mendatang serta merumuskan cara untuk memenuhi

keinginan dan kebutuhan tersebut.

Inovasi yang dilakukan dalam perusahaan biasanya dilakukan oleh bagian riset dan pengembangan. Dalam tahap inovasi ini tolok ukur yang digunakan adalah besarnya produk-produk baru, lama waktu yang dibutuhkan untuk mengembangkan suatu produk secara relatif jika dibandingkan perusahaan pesaing, besarnya biaya, banyaknya produk baru yang berhasil dikembangkan.

2. Operasi

Tahap ini merupakan tapan dimana perusahaan secara nyata berupaya untuk memberikan solusi kepada para pelanggannya dalam memenuhi keinginan dan kebutuhan langganan dan

kebutuhan mereka. Kegiatan operasional berasal dari penerimaan pesanan dari pelangan dan berakhir dengan pengiriman produk atau jasa pada pelanggan. Kegiatan ini lebih mudah diukur kejadiannya yang rutin dan terulang. 


\section{Layanan purna jual}

Dalam tahap ini perusahaan berupaya memberikan manfaat tambahan kepada para pelangan yamg telah membeli produk-produknya dalam bentuk berbagai layanan pasca transaksi.

Beberapa hal yang termasuk dalam layanan purna jual diantaranya seperti garansi produk, service purna jual, serta berbagai pelayanan menegnai keluhan-keluhan pelanggan atas produk maupun jasa yang telah diberikan.

\section{Perspektif Pembelajaran dan Pertumbuhan}

Perspektif keempat dalam Balanced Scorecard mengembangkan pengukuran dengan tujuan untuk mendorong organisasi agar berjalan dan tumbuh. Tujuan dari perspektif pembelajaran dan pertumbuhan adalah menyediakan infrastruktur untuk mendukung pencapaian tiga perspektif sebelumnya. Perspektif keuangan, pelanggan dan sasaran dari proses bisnis internal dapat mengungkapkan kesenjangan antara kemampuan yang ada dari orang, sistem dan prosedur dengan apa yang dibutuhkan untuk mencapai suatu kinerja yang handal. Adapun faktor-faktor yang harus diperhatikan dalam mengatasi hal tersebut agar mampu perusahaan mampu bertumbuh dan berkembang adalah (Chamdan, 2010) :

1. Karyawan

Hal yang perlu ditinjau adalah kepuasan karyawan dan produktivitas kerja karyawan. Untuk mengetahui tingkat kepuasan karyawan perusahaan perlu melakukan survei secara reguler.

Beberapa elemen kepuasan karyawan adalah keterlibatan dalam pengambilan keputusan, pengakuan, akses untuk memperoleh informasi, dorongan untuk melakukan kreativitas dan inisiatif serta dukungan dari atasan. Produktivitas kerja merupakan hasil dari pengaruh agregat peningkatan keahlian moral, inovasi, perbaikan proses internal dan tingkat kepuasan konsumen. Di dalam menilai produktivitas kerja setiap karyawan dibutuhkan pemantauan secara terus-menerus.

2. Kemampuan Sistem Informasi

Perusahaan perlu memiliki prosedur informasi yang mudah dipahami dan mudah dijalankan. Tolok ukur yang sering digunakan adalah bahwa informasi yang dibutuhkan mudah didapatkan, tepat dan tidak memerlukan waktu lama untuk mendapat informasi tersebut.

3. Motivasi, pemberdayaan dan keselarasan

Pegawai yang memiliki informasi yang berlimpah tidak akan memberikan kontribusi pada keberhasilan usaha, apabila mereka tidak mempunyai motivasi untuk bertindak selaras dengan tujuan perusahaan atau tidak diberi kebebasan dalam pengambilan keputusan atau bertindak

\section{Penelitian Terdahulu.}

Adanya penelitian yang dilakukan ini tentunya tidak terlepas dari hasil-hasil penelitian sebelumnya yang dapat digunakan sebagai dasar teori serta kaitannya dengan relevansi atas penelitian ini. S. Yudi Nugroho, dkk memperoleh hasil pengukuran kinerja yaitu :

1. Dilihat dari perspektif keuangan dengan indikator LDR dari tahun 2008 ke tahun 2009 mengalami peningkatan, sedangkan tahun 2010 mengalami penurunan, untuk ROA mengalami peningkatan dari tahun ke tahun. Dari sisi PMS mengalami peningkatan rasio selama 3 tahun berturut-turut yang berarti semakin membaik. Sedangkan GRS pada 
tahun 2009 dan 2010 terjadi penurunan yang cukup signifikan. Kenyataan ini memberikan gambaran yang tidak baik bagi koperasi pada masa yang akan datang disebabkan volume usaha cenderung semakin menurun.

2. Dilihat dari perspektif pelanggan dengan indikator Customer Retention menunjukkan keadaan yang semakin baik dari tahun ke tahun. Untuk Number of New Customer dari tahun 2008 ke 2009 tidak ada penambahan anggota baru dan untuk tahun 2010 terdapat penambahan 1 orang anggota.

Berdasarkan indikator Number of Complain keluhan anggota setiap tahun semakin menurun yang mencerminkan pelayanan yang semakin baik. Sedangkan untuk indikator kepuasan anggota yang dilakukan survei dengan kuesioner secara keseluruhan terhadap atribut koperasi masuk pada kategori baik.

3. Dilihat dari perspektif proses bisnis dengan indikator cycle time secara menyeluruh waktu siklus dicerminkan oleh rata-rata cycle time selama 3 tahun yakni 3 hari yang disebabkan karena ada percepatan waktu yang terjadi setiap tahun hal ini menunjukkan kecenderungan yang baik. Sedangkan untuk indikator yield rate berdasarkan data yang ada realisasi pinjaman terus mengalami penurunan dari tahun 2008 hingga tahun 2010.

4. Dilihat dari perspektif pertumbuhan dan pembelajaran dengan indikator employee productivity produktivitas pengelola hanya naik pada tahun 2009 sedangkan tahun 2010 mengalami penurunan. Untuk employee turn overtidak terdapat tenaga pengelola yang keluar sehingga memberikan gambaran yang baik. Sedangkan jika dilihat berdasarkan indikator absenteeism menunjukkan perkembangan kehadiran cenderung semakin baik. Tingkat kepuasan pengelola secara keseluruhan yang terdiri dari skala kepengurusan, motivasi, kondisi fisik, semangat kerja, dan kompensasi terhadap atribut koperasi masuk pada kategori moderat yang berarti baik.

Selain itu, penelitian yang dilakukan oleh Isroah (2008) yang berjudul diperoleh hasil :

1. Perspektif finansial menunjukkan kinerja sangat baik yaitu tiap-tiap rasio keuangan berada pada kriteria yang paling tinggi nilainya (berdasarkan kriteria Kepmen Usaha Kecil Menengah tahun 2002).

2. Perspektif pelanggan menunjukkan kinerja yang sangat baik yaitu rata-rata persentase atas kepuasan pelanggan sebesar $80.18 \%$

3. Perspektif proses bisnis internal menunjukkan kinerja yang sangat baik dilihat dari ratarata persentase dari proses inovasi sebesar $62,46 \%$ berarti dapat dikategorikan cukup baik, ratarata persentase dari proses opersional sebesar $83,53 \%$ berarti dapat dikategorikan sangat baik, rata-rata proses pelayanan sebesar $80,85 \%$ berarti dapat dikategorikan sangat baik.

4. Perspektif pertumbuhan dan pembelajaran berkaitan dengan kemampuan karyawan terdiri dari komponen Employee Satisfaction rata-rata persentase sebesar 84,12\% berarti dapat dikategorikan sangat baik, Employee retention dengan rata-rata persentase 76,32\% berarti dapat dikategorikan baik, Employee productivity dengan rata-rata persentase $43.17 \%$ berarti dapat dikategorikan cukup baik. Berkaitan dengan kemampuan sistem informasi rata-rata persentase sebesar $81,68 \%$ berarti dapat dikategorikan sangat baik.

Berbagai penelitian Balanced Scorecard yang dilakukan dalam menilai kinerja berbagai jenis badan usaha berbentuk koperasi memang telah banyak dilakukan. Rata-rata hasil dari 
penelitian yang dilakukan memang cukup relevan dan mumpuni dalam memberikan penilaian kinerja koperasi yang menjadi obyek penelitian. Balanced Scorecard mampu menunjukkan indikator-indikator secara lebih detail dan menyeluruh. Indikator mana yang masih kurang dan mana yang sudah baik menjadi bahan evaluator bagi koperasi dalam menilai dan menentukan rencana strategik yang akan dilakukan selanjutnya agar hasil kinerja selanjutnya dapat meningkat dengan tujuan akhir hasil kinerja keuangan yang lebih baik.

\section{METODE PENELITIAN}

\section{Objek Penelitian}

Objek yang dipilih dalam penelitian ini adalah Unit Simpan Pinjam Kopari Catra Gemilang Magelang (selanjutnya disebut USP Kopari Catra Gemilang Magelang) yang terletak di Jalan Balaputradewa no. 9 Borobudur, Magelang, dengan alasan bahwa penerapan Balanced Scorecard dalam mengukur kinerja koperasi merupakan langkah strategik yang berdampak besar terhadap kemampuan manajemen Koperasi Catra Gemilang Magelang dalam melipatgandakan kinerjanya, baik ditinjau dari aspek Keuangan maupun aspek NonKeuangan.

\section{Populasi}

populasi yang digunakan adalah :

a. Para anggota aktif Unit Simpan Pinjam (USP) Kopari Catra Gemilang yang berjumlah 453 orang yang akan digunakan untuk menilai kepuasaan anggota pada aspek konsumen.

b. Karyawan USP Kopari Catra Gemilang Magelang yang berjumlah 5 orang yang akan digunakan untuk menilai kepuasan karyawan pada aspek pertumbuhan dan pembelajaran.

c. Seluruh data-data USP Kopari Catra Gemilang Magelang dari sejak awal berdiri hingga saat ini.

\section{Sampel}

$$
\mathrm{n}=\frac{\mathrm{N}}{\mathrm{N} \cdot \mathrm{e}^{2}+1} \mathrm{453}
$$

\section{Analisis Kualitatif}

Analisa ini digunakan untuk menganalisis masalah dengan menggunakan bahasa verbal berdasarkan tabulasi data penelitian yang dihubungkan dengan teori yang ada dan dimaksudkan untuk memperjelas hasil perhitungan kuantitatif. Metode analisis ini dinyatakan dalam bentuk uraian yang terkait dengan pengukuran kinerja dan efektifitasnya.

\section{Analisis Kuantitatif}

\section{Perspektif Keuangan}

Untuk melihat seberapa jauh keberhasilan yang dicapai oleh USP Kopari Catra Gemilang Magelang dapat dilihat pada tingkat kesehatan dari sisi keuangan. Adapun analisis yang akan digunakan dalam perspektif keuangan ini adalah current ratio, ROA, dan ROE. Tabel pengukuran kinerja di bawah ini disesuaikan dengan rasio yang digunakan dalam penelitian ini. 
Menurut Tugas Akhir no. 10/TA.Akt.051, karya Novika Pujo Arifian : 2010, menyebutkan bahwa Standar yang digunakan dalam pengukuran kinerja keuangan koperasi menurut Kementrian Koperasi dan UMKM RI adalah sebagai berikut :

Tabel 1

Standar Pengukuran Kinerja Koperasi

\begin{tabular}{llll}
\hline Komponen & Standar & Nilai & Kriteria \\
\hline 1. Likuiditas & & & \\
Current Ratio & $175 \%-200 \%$ & 100 & Sangat Baik \\
& $150 \%-174 \%$ & 75 & Baik \\
& $125 \%-149 \%$ & 50 & Cukup Baik \\
& $100 \%-125 \%$ & 25 & Kurang Baik \\
& $<100 \%$ & 0 & Buruk
\end{tabular}

2. Profitabilitas

Return on Asset (ROA)

$\begin{array}{lll}\geq 10 \% & 100 & \text { Sangat Baik } \\ 7 \%-10 \% & 75 & \text { Baik } \\ 4 \%-6 \% & 50 & \text { Cukup Baik } \\ 1 \%-3 \% & 25 & \text { Kurang Baik } \\ <1 \% & 0 & \text { Buruk }\end{array}$

3. Rentabilitas

Rentabilitas Modal Sendiri (ROE)

$\begin{array}{lll}\geq 21 \% & 100 & \text { Sangat Baik } \\ 15 \%-20 \% & 75 & \text { Baik } \\ 10 \%-14 \% & 50 & \text { Cukup Baik } \\ 3 \%-9 \% & 25 & \text { Kurang Baik } \\ <3 \% & 0 & \text { Buruk }\end{array}$

Sumber : TA no. 10/TA.Akt.051, Novika Pujo Arifian : 2010

Rasio likuiditas, profitabilitas, dan rentabilitas mengikuti skala 5 likert dengan derajat 5 sangat baik, dan 1 buruk.

\section{Perspektif Konsumen (Customer Acquisition)}

Merupakan salah satu indikator dalam perspektif pelanggan yang mengukur kemampuan koperasi memperoleh anggota baru. Akuisisi pelanggan akan semakin baik jika semakin mendekati $100 \%$. Berdasarkan penelitian yang dilakukan oleh Sri Wahyuni yang berjudul Analisis Balanced Scorecard Sebagai Alat Pengukuran Kinerja Pada PT. Semen Bosowa Maros (2011) disebutkan bahwa apabila terjadi kenaikan dari periode sebelumya dapat dikatakan baik, begitu pula sebaliknya. Dikatakan kurang baik apabila terjadi penurunan dari periode sebelumnya.

Tingkat kepuasan anggota Menghitung rata-rata kepuasan anggota dengan memberi nilai pada jawaban kuesioner sesuai tingkat kepuasan yang dirasakan. Nilai yang diberikan menggunakan dasar skala Likert 1-5.

Tingkat kepuasan anggota, Perspktif bisnis internasional, perspektif pembelajaran dan pertumbuhan (employe turn over, kepuasan karyawan).

\section{HASIL ANALISIS DAN PEMBAHASAN}

Berdasarkan uji indikator setiap variabel semua valid dan reliabel. Berdasarkan perspektif keuangan, rasio likuiditas, Hasil perhitungan current ratio tahun 2014 diperoleh angka rasio 
sebesar 171,22 \%. Ini berarti bahwa setiap Rp 1,00 hutang lancar dijamin oleh Rp 1,71 aktiva lancar. Hasil tersebut jika dibandingkan dengan standar klasifikasi penilaian koperasi maka current ratio tahun 2014 yang dimiliki oleh Unit Simpan Pinjam Kopari Catra Gemilang Magelang dalam keadaan baik. Rasio probabilitas, Hasil perhitungan Return On Asset tahun 2014 diperoleh angka rasio sebesar 0,43\%. Ini berarti bahwa setiap Rp 1,00 aktiva menghasilkan laba bersih $\mathrm{Rp}$ 0,0043. Hasil tersebut jika dibandingkan dengan standar klasifikasi penilaian koperasi maka Return On Asset tahun 2014 yang dimiliki oleh Unit Simpan Pinjam Kopari Catra Gemilang Magelang dalam keadaan buruk. Rasio reentabilitas, Hasil perhitungan Return On Equity tahun 2014 diperoleh angka rasio sebesar 70,23\%. Ini berarti bahwa setiap Rp 1,00 modal sendiri menghasilkan laba bersih Rp 0,70. Hasil tersebut jika dibandingkan dengan standar klasifikasi penilaian koperasi maka Return On Equity tahun 2014 yang dimiliki oleh Unit Simpan Pinjam Kopari Catra Gemilang Magelang dalam keadaan sangat baik.

Perspektif konsumen, Customer Acquisition, Hasil perhitungan kemampuan USP Kopari Catra Gemilang Magelang tahun 2014 dalam memperoleh anggota baru didapatkan hasil 11,02\% sedangkan hasil dari periode sebelumnya diperoleh 6,80\%. Hasil ini menunjukkan adanya peningkatan sebesar $4,22 \%$ dari periode sebelumnya. Sesuai dengan batasan kriteria penilaian yang telah ditentukan bahwa jika ada peningkatan dari periode sebelumnya dapat dikatakan baik dan jika menurun dari periode sebelumnya dapat dikatakan kurang baik, maka dari hasil ini kemampuan USP Kopari Catra Gemilang dapat dikatakan baik.

Kepuasan anggota, Hasil perhitungan rata-rata ketiga indikator diperoleh nilai 4,3 yang artinya kepuasan anggota USP kopari Catra Gemilang dapat dikatakan sangat puas.

Perspektif bisnis internal, Berdasarkan perhitungan diatas, untuk proses pelayanan kredit diperoleh hasil 0,5. Hasil ini jika dibandingkan dalam kriteria penilaian yang telah ditentukan sebelumnya maka dapat dikatakan cukup baik. Kemudian untuk proses pelayanan menabung diperoleh hasil 0,67. Hasil ini jika dibandingkan dengan kriteria penilaian maka dapat dikatakan baik.

Perspektif Pembelajaran dan Pertumbuhan, Employee Turn Over, Berdasarkan perhitungan diperoleh angka rasio perputaran karyawan sebesar $0 \%$. Hal ini sesuai dengan kriteria penilaian yang telah ditentukan maka hasilnya dapat dikatakan sangat baik.

Tingkat Kepuasan Karyawan, hasil perhitungan dapat diketahui bahwa rata-rata kepuasan karyawan USP Kopari Catra Gemilang dalam bekerja adalah sebesar 3.75 yang artinya karyawan merasa puas selama bekerja di USP Kopari Catra Gemilang Magelang.

Pengukuran Rata-rata Keempat Perspektif, diperoleh nilai 3,88. Hasil ini jika dibandingkan sesuai dengan kriteria penilaian rata-rata dengan skala likert 1-5 yang telah ditentukan pada bab sebelumnya maka dapat disimpulkan bahwa pengukuran kinerja USP Catra Gemilang Magelang Tahun 2014 diperoleh hasil baik.

\section{KESIMPULAN}

1. Perspektif Keuangan

Dari analisis perspektif keuangan diperoleh hasil sebagai berikut :

a. Rasio likuiditas yang diukur dengan current ratio pada tahun 2014 memperoleh hasil $171,22 \%$ menunjukkan kemampuan USP Kopari dalam membayar kewajiban jangka pendeknya dengan aktiva yang dimilikinya baik. 
b. Rasio profitabilitas yang diukur dengan Return On Asset pada tahun 2014 memperoleh hasil $0,43 \%$ menunjukkan kemampuan USP Kopari dalam memperoleh laba dengan return kekayaannya buruk.

c. Rasio rentabilitas yang diukur dengan Return On Equity pada tahun 2014 memperoleh hasil $70,23 \%$ menunjukkan kemampuan USP Kopari dalam memperoleh laba dengan modal sendiri sangat baik.

2. Perspektif Konsumen

Dari analisis perspektif konsumen diperoleh hasil sebagai berikut :

a. Customer Acquisition USP Kopari tahun 2014 naik sebesar 4,22\% dari periode tahun sebelumnya yang menunjukkan kemampuan USP Kopari dalam memperoleh anggota adalah baik.

b. Tingkat kepuasan anggota yang diukur berdasarkan 3 indikator yaitu kepuasan pelayanan kredit, kepuasan pelayanan menabung dan kepuasan pelayanan organisasi memperoleh hasil rata-rata nilai 4,3 yang menunjukkan bahwa anggota sangat puas dengan pelayanan USP Kopari.

3. Perspektif Bisnis Internal

Dari analisis perspektif bisnis internal diperoleh hasil sebagai berikut :

a. Pada MCE kredit diperoleh hasil cukup baik dengan perolehan nilai sebesar 0,5.

b. Pada MCE simpanan diperoleh hasil baik dengan perolehan nilai sebesar 0,67.

4. Perspektif Pembelajaran dan Pertumbuhan Dari analisis perspektif pembelajaran dan pertumbuhan diperoleh hasil sebagai berikut :

a. Employee Turn Over memperoleh hasil sebesar $0 \%$ yang menunjukkan rasio perputaran karyawan sangat baik.

b. Tingkat kepuasan karyawan memperoleh hasil rata-rata nilai 3,75 yang menunjukkan bahwa karyawan puas dalam bekerja di USP Kopari.

5. Pengukuran kinerja USP Kopari Catra Gemilang Magelang tahun 2014 menggunakan analisis Balanced Scorecard yang diukur melalui keempat perspektif sesuai variabel dalam penelitian ini memperoleh hasil rata-rata nilai sebesar 3,88 yang menunjukkan bahwa kinerja USP Kopari tahun 2014 dapat dinyatakan baik.

\section{SARAN}

Berdasarkan kesimpulan yang diperoleh dalam penelitian ini, saran yang dapat disampaikan adalah sebagai berikut :

1. Unit Simpan Pinjam Kopari Catra Gemilang hendaknya berusaha untuk lebih memperhatikan kondisi keuangan pada SHU yang diperoleh dan berupaya lebih baik untuk dapat meningkatkan prosentase perolehan SHUnya.

2. Kemampuan pelayanan yang baik terhadap anggota layaknya dipertahankan agar kepuasan anggota tetap terjaga sehingga mampu diperoleh umpan balik yang baik dari keaktifan anggotanya.

3. Pihak manajemen Kopari Catra Gemilang Induk diharapkan mampu mempertahankan kepuasan karyawan Unit Simpan Pinjam dalam bekerja untuk dapat menghindarkan dari aktivitas penyalahgunaan oleh karyawan karena pekerjaan yang beresiko terkait dengan keuangan. Selain itu pula dengan mempertahankan hal ini mampu menunjukkan bahwa berita mengenai prestasi baik yang diperoleh Kopari Catra Gemilang adalah benar adanya. 
4. Untuk penelitian selanjutnya mengenai pengukuran kinerja menggunakan balanced scorecard dapat ditambahkan dengan variabel penelitian lain yang lebih beragam sehingga penelitian dapat menjadi lebih komprehensif dan akurat.

\section{DAFTAR PUSTAKA}

Arikunto, Suharsimi, (2006), Prosedur Penelitian Suatu Pendekatan Praktik. Jakarta: Rineka Cipta.

Sugiyono, (2010), Metode Penelitian Kuantitatif Kualitatif dan R\&D. Bandung: Alfabeta.

Umar, Husein, (2007), Riset Akuntansi, Dilengkapi Dengan Panduan Membuat Skripsi dan Empat Belas Kasus Bidang Akuntansi. Jakarta: Gramedia

Keputusan Menteri Koperasi dan UKM nomor 96/Kep/M.KUKM/IX/2004 tentang Pedoman Standar Operasional Manajemen Koperasi Simpan Pinjam dan Unit Simpan Pinjam Koperasi.

Kaplan, Robert S., Norton, David P. (Peter S. Yosi Pasla, Penerjemah), (2000), Balanced Scorecard: Menerapkan Strategi Menjadi Aksi. Jakarta: Erlangga.

Mulyadi, (2009), Sistem Terpadu Pengelolaan Kinerja Personel Berbasis Balance Scorecard. Yogyakarta

Mulyadi, (2005). Alternatif Pemacuan Kinerja Personel dengan Pengelolaan Kinerja Terpadu Berbasis Balanced Scorecard. Jurnal Ekonomi dan Bisnis Indonesia. Vol.20, No.3.

Tjahjono, Heru Kurnianto, (2006), Budaya Organisasional dan Balanced Scorecard, Dimensi Teori dan Praktek. UPFE-UMY, Yogyakarta.

Chamdan, Nurul Umam Nurwafi, (2010), Penerapan Metode Balanced Scorecard Sebagai Pengukuran Kinerja Pada Lembaga Keuangan Syariah (BMT) Bina Insan Mandiri Gondangrejo. Skripsi Sarjana FKIP UNS.

Arifian, Novika Pujo, (2010), Analisa Laporan Keuangan Pada Koperasi Simpan Pinjam Jasa Cabang Batang Tahun 2007-2009. Tugas Akhir no. 10/TA.Akt.051 UNNES

Tjiptono, Fandy, (2005). Prinsip-prinsip Total Quality Service. Yogyakarta: Andi Wardani, Hari Susanta, Agung Budiatmo, (2012), Analisis Balanced Scorecard Pada Koperasi Karyawan Krama Yudha Ratu Motor Jakarta. Jurnal Ilmu Administrasi Bisnis. http://ejournals1.undip.ac.id.

Pratiwi, Umi, (2010), Balanced Scorecard dan Manajemen Strategik. Jurnal Manajemen dan Akuntansi. Vol. 11, No. 2: 166-174.

Wahyuni, Sri, (2011), Analisis Balanced Scorecard Sebagai Alat Pengukuran Kinerja Pada PT. Semen Bosowa Maros. Skripsi Sarjana FE UNHAS

Indranata, I Gst.Ngr.Agung L., Suryanawa, I Ketut, (2013), Pengukuran Kinerja Berbasis Balanced Scorecard Pada Koperasi Serba Usaha Kuta Mimba.

E Jurnal Akuntasi Universitas Udayana 4.3: 459 Zulaikha, (2009), Kemungkinan Balanced Scorecard dalam Mengevaluasi Kinerja Operasi. Skripsi Sarjana di Universitas Muhammadiyah Surakarta.

Sipayung, Friska, (2009), Balanced Scorecard: Pengukuran Kinerja Perusahaan dan Sistem Manajemen Strategis. Jurnal Manajemen Bisnis. Vol. 2, No.1: 7-14.

Wisnubroto, Petrus, Nenny Indrawati, (2008), Analisis Pengukuran Kinerja Dengan Menggunakan Metode Balanced Scorecard. Jurnal Teknologi. Vol. I, No.2: 178-190. 